\title{
Risk Assessment at the Design Phase of Construction Projects in Ghana
}

\author{
Maurice Azochiman Awuni \\ University for Development Studies, Tamale, Ghana \\ Email: maumeloneusa@yahoo.com
}

How to cite this paper: Awuni, M.A. (2019) Risk Assessment at the Design Phase of Construction Projects in Ghana. Journal of Building Construction and Planning Research, 7, 39-58.

https://doi.org/10.4236/jbcpr.2019.72004

Received: January 21, 2019

Accepted: June 3, 2019

Published: June 6, 2019

Copyright (อ 2019 by author(s) and Scientific Research Publishing Inc. This work is licensed under the Creative Commons Attribution International License (CC BY 4.0).

http://creativecommons.org/licenses/by/4.0/

\begin{abstract}
The study was carried out exclusively in Ghana to explore the approaches employed by consultants in risk assessment at the design phase of projects in Ghana. One hundred and fourteen (114) consultants were selected out of a population of one hundred and eighty six (186) from three main professional associations in Ghana made up of the Ghana Institute of Architects, Ghana Institution of Engineers and the Ghana Institution of Surveyors (Quantity Surveying Division) practicing in Ghana for the study. Both primary and secondary data were collected. A descriptive survey was also used to observe and describe the presence, frequency or absence of characteristics of a phenomenon as it naturally occurred, in order to gain additional information. A questionnaire was also designed to collect data from the architects, engineers and quantity surveyors. The data was analyzed using Statistical Package for the Social Scientists (SPSS) 17.0. Descriptive and inferential statistics, such as frequency tables, percentages and cross tabulations were used in the data analysis and summaries. Simple tests of associations were undertaken by using Chi square and Cramer's V statistics to compare relationships between variables. Again, relative importance index was also used to analyze some of the data by computing to deduce their rankings. The relative importance index was used to analyze some of the data by computing to deduce their rankings. The research revealed that majority of consultants had an average knowledge of risk management. Based on the findings it was recommended that consultants undergo advanced training in risk assessment. It was therefore suggested that consultancy firms should develop a set of laid down procedures for consultants to use in risk assessment in order that the use of intuition employed by majority is lessened. The challenges observed in risk assessment and the remedial steps suggested curtailing the detrimental effects of risks would be of wide importance to many developing economies.
\end{abstract}

\section{Keywords}

Construction, Industry, Project, Risk, Management, Assessment, Design Phase 


\section{Introduction}

Globally, public infrastructure services are fast outpacing the resources for providing them [1], the construction industry which proffers these needs is directly linked to the economy with the government being the biggest client [2] and [3]. Again, the importance of the industry cannot be overemphasized as it is evidenced by its average revenue flows, which generally represent some $25 \%$ of the budget revenue and 6\% of Gross Domestic (GDP) in Ghana [4]. These socio-economic realities have underscored the need for more innovative ways to achieve value for money in construction projects in Ghana [1]. Any improvement in the construction industry will therefore have a direct and substantial impact on the overall economic situation of the country and result in budgetary savings and efficiency in government expenditures.

A haunting specter of inefficiencies attracting criticisms in outcomes such as time, cost overruns and poor quality [5] [6] [7] and [8] has however bedeviled the construction industry. Construction projects are failing due to prevalent risks [9]. The industry perhaps more than most, is plagued by different kinds of risks (e.g., environmental, physical, political, social and economic risks) [10], which are not often dealt with adequately resulting in poor performance [11]. However, according to Agyakwa-Baah [2] most consultants (Architects, Engineers and Quantity Surveyor) do not predict risks and even if risks are predicted, they are dealt with in a completely arbitrary way by adding $10 \%$ contingency onto the estimated cost of a project. This phenomenon is very worrying considering the influence that risk has on project objectives i.e., cost, time and quality [12].

In response to this type of situation, Andi et al. [13] and Faridi et al. [14] therefore intimated that risk assessment should form a major element in the design phase of construction projects. According to Uher et al. [15] it is at the design phase, i.e. Programming and feasibility, Schematic, Design development; and Contract documentation that the greatest degree of uncertainty about the future is encountered. The construction industry in Ghana in particular has been slow to realize the potential benefits of risk assessment [10] at the design phase of construction. The limited use of risk assessment is however very surprising considering the presence of risk and uncertainty at this phase. Recently, [12] opined that intensive research and development have focused on project risk management, however while a good deal of research has been conducted on risk management globally, Ghana as a developing country has not focused on risk assessment at the design phase.

It is against this backdrop that this study was conducted to explore the approaches employed by consultants for risk assessment at the design phase of projects in Ghana. Substantial evidence in literature suggests that construction problems relating to Ghana are similar to the situations in many African and some Asian countries [16] [17] and [18].

The research therefore aims at exploring the approaches employed by consultants in risk assessment at the design phase of projects in Ghana. To achieve this, 
the study examined the extent of knowledge of consultants in risk assessment at the design phase of construction projects; and to examine the influence of consultants in risk assessment construction projects.

\section{Review of Related Literature}

The construction industry is a key sector of the economy of every country [19]. [20] noted that, the industry is important because of the outputs and outcomes of its activities, whilst contributing to national socio-economic development by providing the buildings which are used in the production of all goods in the economy. Moreover, the physical infrastructure, built through construction activity, is the nation's economic backbone as it forms the arteries for the facilitation of productive activity by enabling goods and services to be distributed within and outside the country.

Lopes [21] also observed that in every country, the industry constitutes a large part of the economy. This observation is in tandem with the situation in Ghana as the [22] noted that, an approximate annual value of public project for works and consultant services has been given as US\$600 million [23] representing about $10 \%$ of the country's GDP. Again the industry boosts of an average revenue flow representing about $25 \%$ of the budget and $6 \%$ of the Gross Domestic Product [23]. These observations pointed out emphasize the significance of the industry to the country as its activities have an economic and social effect [1]. Just like other industries, different players are usually involved in the industry in Ghana.

The main players in the industry are clients, consultant and contractors [24]. From the clients perspective there are two main groups of construction clients: public and private [25]. Agyakwa-Baah [2] and Tuuli et al. [3] noted that government is the biggest client in Ghana. A contractor is an organization that provides a service for the client, i.e. executes the construction works. According to Ayirebi-Dansoh [26] construction firms in Ghana are categorized into four financial classes (1 through 4 ) according to the size of individual projects they can bid from the government. The classification by the Ministry of Works and Housing in Ghana has however been observed to be too general and obsolete and the registration criteria, lists of contractors and monetary thresholds are not regularly updated [27] and [28]. From the perspective of consultants, generally they belong to one or more of the three main professional institutions in Ghana i.e. the Ghana Institute of Architects, Ghana Institution of Engineers and the Ghana Institution of Surveyors.

It has conversely been observed by several authors [1] [3] and [23] that the industry perhaps more than most, is plagued by different kinds of risks (e.g., environmental, physical, political, social and economic risks) [10] resulting in poor performance [11]. Tadayon et al. [12] therefore recommended that the industry should be awakened by this occurrence in order that remedial steps are taken to curtail the situation before it reaches crescendo.

Uher et al. [15] examined various structural and cultural factors concerned 
with the implementation of risk management in the conceptual phase of a project life cycle, they found out that the most frequently used approach for risk assessment is the qualitative approach, which uses word form or descriptive scales to describe the magnitude of potential consequences and the likelihood that those consequences will occur. Again Bajaj et al. [29] identified, investigated and evaluated the process of risk identification. They found that the most frequently used method of risk identification is the top-down approach technique, where the project is analyzed from an overall point of view. Baker et al. [30] believed personal and corporate experience, engineering judgement, and brainstorming are effective ways for identifying new risks and for qualitative use.

Carter [31] has undertaken a significant study of the problems involved in the adoption of risk assessment by industrial corporations. In a study of four major oil companies, he found that this was a difficult, time consuming and expensive operation, and that the experience of these companies ranged from "success" to "complete failure". According to Wang et al. [32] a significant step was taken by the New South Wales (NSW) Government in late 1993 when it required agencies under its control to apply risk assessment in planning new projects and major capital asset activities valued in excess of $\$ 5 \mathrm{M}$. The guidelines for undertaking this are set out in a publication entitled Risk Management Guidelines. This document makes the point that risk assessment should begin at the design stage of a project and continue throughout its life.

Discussions of management issues involved in the implementation of risk assessment procedures in organizations can be found in [33] and [34]. The former makes the point that while technical competence is important, the success or failure of risk evaluation "is determined by a whole battery of organisational and behavioural forces" such as organisation readiness to adopt risk assessment, committed support of top and middle level management for acceptance of risk evaluation and for educational needs, availability of good input data and a team approach to performing risk analysis.

Again, [34] have written a widely quoted book dealing with the application of risk analysis to corporate activity. One of the many things discussed there, concerns the importance of management attitudes to the value of risk assessment vis a vis matters such as the high cost of managerial time input, "gut" feeling, and overall "know-how".

To summarise this section, several of those authors have pointed out that most of the encumbrance to the application of risk assessment tools and techniques can be pointed to a knowledge gap in the area; further a late survey by [35] indicated that a significant problem in construction projects has been that the knowledge of risk assessment tends to be poor, hence there is a need to explore this knowledge gap in order that proposal can be made to improve on risk assessment in projects.

\section{Concept of Risk Management and Risk in Construction Projects}

Risk management is a formal and orderly process of systematically identifying, 
analyzing, and responding to risks to obtain the optimum degree of risk elimination, mitigation and/or control [32]. A systematic approach to risk management in construction industry consists of three main stages: a) risk identification; b) assessment; and c) risk response [25]. The risk management process begins with the initial identification of the relevant and potential risks associated with the construction project. The risk management process helps to observe and determine all the risks to which the project is exposed [36]. This according to [25] is of considerable importance since the process of risk assessment and response management may only be performed on identified potential risks.

According to Paulson [37] risk assessment is what we as private persons do every day, e.g. when we decide to take the car instead of the train for a certain trip or when we choose to cross the street outside instead of inside the pedestrian crossing. During risk assessment, identified risks are evaluated and ranked. Risk assessment is the intermediate process between risk identification and management. It incorporates uncertainty in a quantitative and qualitative manner to evaluate the potential impact of risk [38]. There is considerable literature in the area of risk management presented by several authors which is discussed in the following section.

Risk is a multi-facet concept. Research literature offers different definitions of project risk [10] [27] [39] [40] [41] [42] and [43]. As this research discusses risks in the project context, the research has adopted a more general and broad definition of risk as presented by "A Guide to the Project Management Body of Knowledge 2008", there risk is defined as an uncertain event or condition that, if it occurs, has a positive or negative effect on a project's objectives [44].

In addition to the different definitions of risk Smith et al. [24] added that there are various ways for categorizing risk for different purposes. For example, some categorize risks in construction projects broadly into; known risks, "known unknowns" and "unknown unknowns". Known risks include minor variations in productivity and swings in material costs. These occur frequently and are an inevitable feature of all construction projects. "Known unknowns" are the risk events whose occurrence is predictable or foreseeable. Either their probability of occurrence or their likely effect is known. "Unknown unknowns" are those events whose probabilities of occurrence and effect are not foreseeable by even the most experienced staff. Others classify risk in more detailed categories of technology risk, financial risk, contractual risk, political risk, environmental risk, social risk, economic and force majeure risk [14] [38] and [45].

According to Chapman et al. [41] technology risks are the risk factors associated with the technologies involved in the execution methods and operational technology of the project. Financial risk involves issues or concerns associated with the financing of the project [38]. Barber [40] added that contractual risk involves issues or concerns associated with the contractual and project approaches-systems-processes used for both project execution and operation, whilst political risk involves Issues or concerns associated with the local, regional, and national political and regulatory situation confronting the project. Envi- 
ronmental risk involves Issues or concerns associated with the environmental problems [38]. Smith et al. [24] added that social risk involves Issues or concerns associated with the social and cultural impacts of the project to the community and region within which it is to be located whilst economic risk involves issues or concerns associated with the macroeconomic impact of the project to the community and region within which it is to be located [25]. Force majeure risks can also be termed an Act of God, it refers to an event which is beyond a parties' power to control. A war, breakdown of machinery, a strike or fire caused by lightning are examples of force majeure. They consist of such things as fires, earthquakes, tornadoes, hurricanes, riots, and civil commotion. Some other conditions, such as strikes, work slowdowns, and labor shortages, which are normally called "acts of man," are often included [46].

\section{Theoretical Framework for Risk Assessment}

Several frameworks can be found in literature, the [47] framework involves four steps, establish context, identify risks, analyze risks and evaluate risks; British Standard Project Management framework [48] also consists of four steps which include context, risk identification, risk analysis and risk evaluation and the [49] consists of initiation, preliminary analysis, risk estimation and risk evaluation. Below is a theoretical framework encapsulating the various steps in risk assessment from various authors [47]; [48] and [49] (See Figure 1).

\subsection{Context}

In order to be able to recognize a risk, it is necessary to know what is at risk. According to [47], the first step in the process is to define the context of the risk assessment. The second step is to identify the risk to be managed, the third step

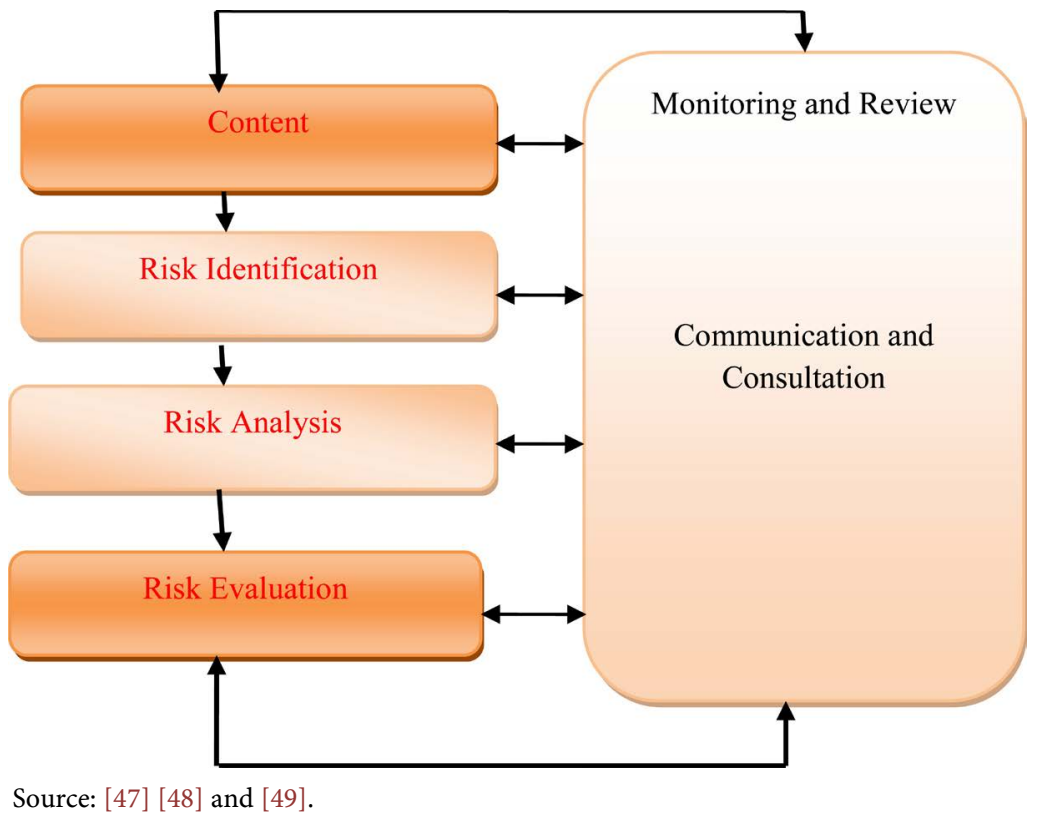

Figure 1. Theoretical framework for risk assessment. 
is to analyze the risk and the fourth step is to evaluate the risk which involves comparing the level of risk found during the analysis process with previously established risk criteria. It is important to understand the environment in which the project is being undertaken relating to the organization, stakeholders, strategy and timeframe, and determine what key elements are relevant to project. Stating the objective and benefits of project within a clearly designed context provides a strong focus for identification of risks.

Context analysis produces the following:

- The financial, operational, client, cultural and legal aspect of the organizations functions;

- A concise set of objectives for the project;

- A note of the stakeholders objectives;

- A summary of the stakeholders' objectives; and

- A small set of success criteria by which the achievement of the projects objectives and so the significance of risks can be measured, giving separate consideration to the likelihood or frequency of an outcome and its impact [48].

\subsection{Risk Identification}

This step seeks to identify the risks to be managed. Comprehensive identification using a well-structured systematic process is critical, because if a potential risk is not identified at this phase it is excluded from further analysis. The tools and techniques used to identify risks include checklists, judgments based on experience and records, flow charts, brainstorming, systems analysis, scenario analysis and systems engineering techniques [47].

\subsection{Risk Analysis}

The objectives of analysis are to separate the minor acceptable risks from the major risks, and to provide data to assist in the evaluation and treatment of risks [48]. Risk analysis involves consideration of the sources of risk, their consequences and the likelihood that those consequences may occur. Factors which affect consequences and likelihood may be identified. Risk is analyzed by combining estimates of consequences and likelihood in the context of existing control measures.

\subsection{Risk Evaluation}

Risk evaluation involves comparing the level of risk found during the analysis process with previously established risk criteria [49]. Risk analysis and the criteria against which risks are compared in risk evaluation should be considered on the same basis. Thus qualitative evaluation involves comparison of a qualitative level of risk against qualitative criteria, and quantitative evaluation involves comparison of numerical level of risk against criteria which may be expressed as a specific number, such as fatality, frequency or monetary value. The output of a 
risk evaluation is a prioritized list of risks for further action. The objectives of the organization and the extent of opportunity which could result from taking the risk should be considered.

\subsection{Monitoring and Review}

It is necessary to monitor risks. Risks and the effectiveness of control measures need to be monitored to ensure changing circumstances do not alter risk priorities. Few risks remain static. Factors which may affect the likelihood and consequences of an outcome may change, as may the factors which affect the suitability or cost of the various treatment options. It is therefore necessary to regularly repeat the risk assessment cycle [15].

\subsection{Communication and Consultation}

According to [50] communication and consultation are an important consideration at each step of the risk assessment process. It is important to develop a communication plan for both internal and external stakeholders at the earliest phase of the process. This plan should address issues relating to both the risk itself and the process to manage it. Communication and consultation involve a two-way dialogue between stakeholders with efforts focused on consultation rather than a one way flow of information from the decision maker to other stakeholders [51].

Effective internal and external communication is important to ensure that those responsible for implementing risk management, and those with a vested interest understand the basis on which decisions are made and why particular actions are required. Perceptions of risk can vary due to difference in assumptions and concepts and the needs, issues and concerns of stakeholders as they relate to the risk or the issues under discussion. Stakeholders are likely to make judgments of the acceptability of a risk based on their perception of risk. Since stakeholders can have a significant impact on the decisions made, it is important that their perceptions of risk, as well as their perceptions of benefits, be identified and documented and the underlying reasons for them understood and addressed [51].

\section{Methodology}

This section discusses the approach to data collection and then the data collection instrument. It provides an overview of the research population and sampling technique and the unit of analysis. The study was carried out exclusively in Ghana. Consultants who by their profession are actors at the design phase of construction projects were drawn from the three main professional associations in Ghana made up of the Ghana Institute of Architects, Ghana Institution of Engineers and the Ghana Institution of Surveyors (Quantity Surveying Division) practicing in Ghana for the study. Consultants were selected because they are the main actors involved at the design phase of construction projects. Contextually, 
the knowledge of consultants in risk assessment at the design phase of construction projects is examined.

The research covered a population of one hundred and eighty six (186) consultants made up of architects, engineers and quantity surveyors within selected consultancy firms in Ghana. The simple random sampling technique was used in selecting each unit of the sample on the basis of chance. All units of the study population were given equal opportunity of being included in the sample [52]. The probability sampling technique was used because it prevents subjectivity, bias, and allows the results to be generalized to the target population.

The sample size for the various consultancy firms was determined using the [53] statistical formula as stated below. According to [54], quantitative research designs require large samples to increase representatives and reduce sampling error.

$$
n=\frac{n^{1}}{\left(1+n^{1} / N\right)}
$$

where: $n=$ Sample Size.

$$
n^{1}=\frac{S^{2}}{V^{2}}
$$

$N=$ Population Size;

$S=$ Maximum standard deviation in the population element;

(Total error $=0.1$ at a confidence level of $95 \%$ );

$V=$ Standard error of sampling distribution $=0.05$;

$P=$ The proportion of the population elements that belong to the defined class $=0.5$.

$$
S^{2}=P(1-P)=0.5(1-0.5)=0.25=\frac{n^{1}}{\left(1+n^{1} / N\right)}
$$

Table 1 specifies the firms identified and the number of respondents selected to respond to the study. Using the above formula, a sample size of 114 people was considered appropriate and representative enough for the study.

Both primary and secondary data were collected. A survey was used to collect original data for describing a population too large to observe directly [55]. The researchers used surveys because according to [56], surveys are used for relatively large number of respondents within a limited time frame. The descriptive

Table 1. Sample size for each of the selected firms.

\begin{tabular}{ccccc}
\hline Item & Firms & Unit of analysis & Consultants & $\begin{array}{c}\text { Number of } \\
\text { sample Frame }\end{array}$ \\
\hline A & Architectural Practicing Firms & Architects & 114 & 54 \\
B & Quantity Surveying Firms & Quantity Surveyors & 51 & 34 \\
C & Civil Works Consultants & Civil engineers & 35 & 26 \\
& Total & & $\mathbf{1 8 6}$ & $\mathbf{1 1 4}$ \\
\hline
\end{tabular}

Source: Field survey, April 2013. 
survey was also used to observe and describe the presence, frequency or absence of characteristics of a phenomenon as it naturally occurs, in order to gain additional information. The primary purpose of a descriptive survey research was to describe the situation, preferences, practices, opinions, concerns or interests of the phenomenon of interests of the phenomenon of interests [54]. Naoum [57] added that the descriptive survey aims to answer such questions as: How many? Who? What is happening? Where? and When? It deals with counting the number of respondents with certain opinions/attitudes towards a specific object. The counting can be later analyzed to compare or illustrate reality and trends. The descriptive study apart from providing valuable base line information, the approach is very flexible and can be used to collect information from a large group of respondents [55]. The descriptive survey was selected because it provides an accurate portrayal or account of the characteristics, for example behavior, opinions, abilities, and knowledge of a particular individual, situation or group [57]. This design was chosen to meet the objectives of the study.

A questionnaire was designed to collect data from architects, engineers and quantity surveyors. These questions were grouped in categories to collect data on knowledge in risk assessment, and the role of consultants in risk assessment at the design phase. The research questions were developed by the researchers and were reviewed by experts in academia and in construction project practice. Subsequently, a pilot test of the questionnaire and interview was conducted for six (6) participants made up of two architects, two engineers and two quantity surveyors in order to identify and eliminate potential ambiguity in the questionnaire. Few questions were reviewed as a result of non-response from the respondents of the pilot study. This was done to improve the reliability and validity of the questionnaire. The questionnaires were self-administered on one-to-one basis and also through the internet to the respondents willing to fill or provide answers to the questionnaire. To improve the response rate, a number of follow-up procedures and strategies were considered, such as sending reminder surveys or notices to non-respondents. The primary data collected was reviewed by the researchers to ensure maximum accuracy, legibility, completeness, consistency and to reduce ambiguity.

The data was analyzed using Statistical Package for the Social Scientists (SPSS) 17.0. Descriptive and inferential statistics, such as frequency tables, percentages and cross tabulations were used in the data analysis and summaries. Simple tests of associations were undertaken by using Chi square and Cramer's V statistics to compare relationships between variables. Again, relative importance index was also used to analyze some of the data by computing to deduce their rankings. The relative importance index was used to analyze some of the data by computing to deduce their rankings.

\section{Discussions}

A total of 114 questionnaires were sent out. Although 67 were returned, 7 were 
rejected because they were not completely filled out; thus, only 60 were included in the analysis for a response rate of 53\%. Akintoye et al., [50] argued that this is well above the norm of $20 \%-30 \%$ for questionnaires for use in the construction industry. The response rate was therefore deemed adequate for the purposes of data analysis.

Table 2 discusses the number of years respondents have been engaged in construction projects. A cross tabulation was used to analyze their responses. Of the total population of 60 respondents, majority of the respondents (55) had been engaged in construction projects. Out of the 55 respondents, $25 \%$ had 0 - 5 years' experience whilst $75 \%$ had over five (5) years' experience. This means that the results represent the point of view of consultants who have a lot of experience in Construction projects.

Table 3 is a cross tabulation of the various variables. The authors used cross tabulation method to test the relationship between years of experience and engagement in project; relationship between years of experience and participation at the design phase of project; and relationship between frequency with which consultants carry out risk assessment at the design phase and whether consultants had studied risk assessment before at 3 degrees of freedom using the Chi Square test. The null hypotheses were that there were no relationships between years of experience and engagement in construction project; years of experience and participation in the design phase of project; and how frequent consultants carry out risk assessment at the design phase and whether consultants had studied risk assessment before. While the alternate hypotheses indicated that there were relationships between the variables used. The criteria for acceptability of the test results were the significance probability p-value of alpha $=0.05$ using $95 \%$ Confidence Interval. Test values with significance of $<0.05$ were considered statistically significant. While those with significance $>0.05$ provide enough evidence not to reject the null hypotheses. Results of the cross tabulation indicates p-value 0.019 for the relationship between years of experience and engagement and relationship between years of experience and participation at the design phase of project which is $<0.05$. This therefore provides evidence of significant association between the dependent and independent variables. Thus,

Table 2. Years of experience Engagement in any construction project. Cross tabulation.

\begin{tabular}{cccc}
\hline & \multicolumn{2}{c}{ Engagement in any construction project } & \multirow{2}{*}{ Total } \\
\cline { 2 - 3 } Years of Experience in Project & Yes & No & Freq (\%) \\
\cline { 2 - 3 } & Freq (\%) & Freq (\%) & $18(30.0)$ \\
$0-5$ yrs & $14(25.0)$ & $4(100.0)$ & $27(45.0))$ \\
$11-15 \mathrm{yrs}$ & $27(48.2)$ & $0(0.0)$ & $7(11.7)$ \\
$\geq 15 \mathrm{yrs}$ & $7(12.5$ & $0(0.0)$ & $8(13.3)$ \\
Total & $8(14.3)$ & $0(0.0)$ & $60(100.0)$ \\
\hline
\end{tabular}

Source: Field survey, April 2013. 
Table 3. Chi-Square Test for relationships.

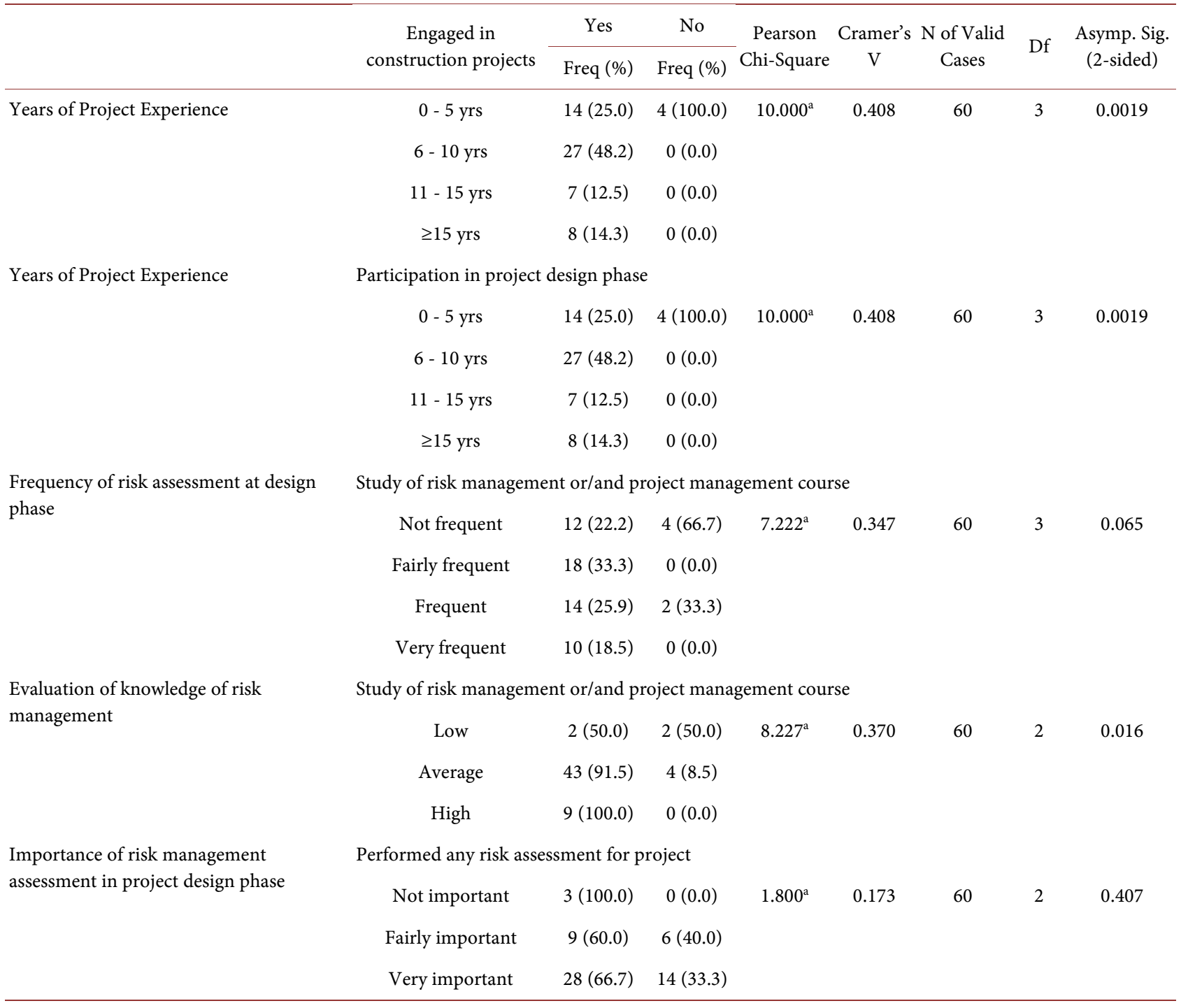

Source: Field survey, April 2013.

years of experience of respondents and engagement and years of experience and participation at the design phase in project are related. Results of the cross tabulation of the relationship between frequency with which consultants carry out risk assessment at the design phase and whether consultants had studied risk assessment before however, indicate $\mathrm{p}$-value of 0.065 which is $>0.05$. T; this therefore provides evidence not to reject the null hypothesis in the current study. The implication of this test is that the frequency with which consultants carry out risk assessment at the design phase and whether consultants had studied risk assessment before are not related. The observation that there is no relationship between how frequent consultants carry out risk assessment at the design phase and whether consultants had studied risk assessment before also lends credence to the fact that even though majority of respondents indicated that they had studied risk management before, many respondents (30) either do not frequently or 
fairly frequently carry out risk assessment (Refer Table 3).

The Cramer's V statistics show the extent to which years of experience of respondents is related to engagement and years of experience and participation at the design phase is also related in construction projects. It was therefore found out that the Cramer's V of both variables with effect size 0.019 falls between 0.00 and 0.10 . This shows that there is a negligible association between years of experience and engagement and years of experience and participation at the design phase in construction project. This means that even though there is a relationship between years of experience and engagement and years of experience and participation at the design phase in project, the level of relationship is insignificant.

To test the relationships between whether respondents had studied risk assessment or/and project management courses and how respondents evaluate their knowledge in risk assessment and the relationship between whether respondents had carried out risk assessment for project before and how respondents assess the level of importance of risk assessment at the design phase, the authors used cross tabulation at 2 degrees freedom. The null hypothesis states that there is no relationship between whether respondents had studied risk assessment or/and project management courses and how respondents evaluate their knowledge in risk assessment. Whilst the alternate hypothesis is that there is a relationship. Results of the cross tabulation indicates p-value (0.016); this therefore provides evidence against the null hypothesis. The implication of this is that, the null hypothesis is rejected, therefore there is a relationship between whether respondents had studied risk assessment or/and project management courses and how respondents evaluate their knowledge in risk assessment are related. Invariably, the relationship between whether respondents had carried out risk assessment for project before and how respondents assess the level of importance of risk assessment at the design phase, the p-value of (0.407) provides evidence against the null hypothesis. The implication of this is that, the null hypothesis is rejected, on the basis of the sample; there is a relationship between whether respondents had carried out risk assessment for project before and how respondents assess the level of importance of risk assessment at the design phase. The Cramer's V with effect size 0.016 falls between 0.00 and under 0.10 ; this shows that there is a negligible association between whether respondents had studied risk assessment or/and project management course and how respondents evaluate their knowledge in risk assessment while the Cramer's $\mathrm{V}$ with effect size 0.407 falls between 0.40 and under 0.60. In terms of the level of magnitude of association, the result shows that there is a relatively strong association between how consultants assess the importance of risk assessment and whether consultants carry out risk assessment.

Risk assessment was conducted at various phases of project. The study sought to find out from respondents the phase or phases of project in which they had conducted risk assessment before. Table 4 shows the various phases in project where respondents had carried out risk assessment before. From the analysis of 
the results, it can be seen that the phase where majority of respondents (20 representing 33\%), undertake risk assessment is the tendering/contract award phases. This may be as a result of the fact that during tendering/contract award phase, evaluation of tenders submitted by the tenderers is a major activity. Even though majority of the respondents $70 \%$ indicated that risk assessment was important at the design phase, it was worrying to find out that only 14 representing $23 \%$ of the respondents undertake risk assessment only at the design phase and 2 at both the design and production phase.

Table 5 is the responses of consultants who were asked to evaluate how frequent they carried out the different kinds of risks that could be found in projects. From the analysis of Table 5, it can be observed that majority of respondents frequently assess financial risks which is ranked $1^{\text {st }}$ and contractual risks which is also ranked $2^{\text {nd }}$. The others follow suit from the highest ranked to

Table 4. Phase of the project where risk assessment processes were performed ${ }^{*}$ Importance of risk assessment at the design phase of projects. Cross tabulation.

\begin{tabular}{ccccc}
\hline $\begin{array}{c}\text { Project phase of risk assessment } \\
\text { processes performance }\end{array}$ & \multicolumn{2}{c}{$\begin{array}{c}\text { Importance of risk assessment at design } \\
\text { phase of project }\end{array}$} & Total \\
\cline { 1 - 3 } & $\begin{array}{c}\text { Not so } \\
\text { important }\end{array}$ & $\begin{array}{c}\text { Fairly } \\
\text { important }\end{array}$ & $\begin{array}{c}\text { Very } \\
\text { important }\end{array}$ & \\
\cline { 2 - 4 } & Freq (\%) & Freq (\%) & Freq (\%) & Freq (\%) \\
\hline Design & $0(0.0)$ & $0(0.0)$ & $14(100.0)$ & $14(100.0)$ \\
E Tendering/Contract Award & $0(0.0)$ & $6(42.9)$ & $8(55.1)$ & $14(100.0)$ \\
E Production & $0(0.0)$ & $0(0.0)$ & $4(100.0)$ & $4(100.0)$ \\
E Design and Production & $0(0.0)$ & $0(0.0)$ & $2(100.0)$ & $2(100.0)$ \\
E Tendering/Contract and Production & $3(50.0)$ & $3(50.0)$ & $0(0.0)$ & $6(100.0)$ \\
E NA & $0(0.0)$ & $6(30.0)$ & $14(70.0)$ & $20(100.0)$ \\
E Total & $3(5.0)$ & $\mathbf{1 5 ( 2 5 . 0 )}$ & $\mathbf{4 2 ( 7 0 . 0 )}$ & $\mathbf{6 0 ( 1 0 0 . 0 )}$ \\
\hline
\end{tabular}

Source: Field survey, April 2013.

Table 5. Risks frequently assessed in project.

SCALE

\begin{tabular}{ccccccc}
\hline Risk & Not Frequent & Fairly Frequent & Frequent & Very Frequent & RII & Rank \\
\hline Financial Risk & 2 & 4 & 18 & 16 & 80.0 & $1^{\text {st }}$ \\
Contractual Risk & 2 & 10 & 12 & 16 & 76.3 & $2^{\text {nd }}$ \\
Economic Risk & 8 & 12 & 10 & - & 57.5 & $3^{\text {rd }}$ \\
Environmental Risk & 11 & 11 & 14 & 4 & 55.9 & $4^{\text {th }}$ \\
Political Risk & 14 & 12 & 6 & 8 & 55.0 & $5^{\text {th }}$ \\
Technological Risk & 14 & 16 & 8 & - & 46.1 & $6^{\text {th }}$ \\
Social Risk & 20 & 12 & 8 & - & 42.5 & $7^{\text {th }}$ \\
Force Majeure Risk & 25 & 7 & 6 & 2 & 40.6 & $8^{\text {th }}$
\end{tabular}

Source: Field survey, April 2013. 
the lowest ranked as follows, economic risk $3^{\text {rd }}$, environmental risk $4^{\text {th }}$, political risk $5^{\text {th }}$, technology risk $6^{\text {th }}$, social risk $7^{\text {th }}$ and force majeure risk $8^{\text {th }}$. The increase in the number of projects with huge cost overruns and contractual disputes which was also observed by [8] has been a major reason for consultants concentrating on assessing them.

The approach consultants use to assess project risks vary from organization to organization. Data gathered from the field indicates that, majority of consultants $48 \%$ use the informal approach to analyze risk whilst $15 \%$ use the formal approach. This finding supports [24], as it was noted that many organizations implement the informal approach of risk assessment.

Table 6 provides a detailed analysis of the methods frequently used in identifying risks in construction projects. Data from the field showed that consultants used various methods with previous experience been the most frequently used method followed by historical data, expert opinion, brainstorming, evaluation of projects, checklist, structured interview and questionnaires in descending order. This observation is in tandem with a late study by [30], which was noted that personal experience, historical data and brainstorming to be effective ways for identifying new risks.

In analyzing risk, consultants resort to using qualitative or the quantitative method to analyze risk. Analysis of data gathered and analyzed showed that, the qualitative method of risk analysis was ranked 1st indicating that, the qualitative method of risk analysis is the method frequently used by most consultants in Ghana to analyze risk. This result is similar to a questionnaire survey conducted by [58] in China, which showed that qualitative analysis is the most commonly used technique in the Chinese construction industry, while the use of quantitative methods is very low.

Majority of the respondents $43 \%$ assess the level of influence that consultants have on risk assessment at the design phase as very large whilst $3 \%$ as very small. This indicates that the role of the consultant in risk assessment at the design phase of the project of work is very significant.

Table 6. Method frequently used to identify risk.

\begin{tabular}{ccccccc}
\hline $\begin{array}{c}\text { Method for } \\
\text { identifying risk }\end{array}$ & Not Frequent & Fairly Frequent & Frequent & Very Frequent & RII & Rank \\
\hline $\begin{array}{c}\text { Previous Experience } \\
\text { Historical Data }\end{array}$ & - & 4 & 15 & 21 & 85.6 & $1^{\text {st }}$ \\
Expert Opinion & - & 4 & 23 & 11 & 79.6 & $2^{\text {nd }}$ \\
Brainstorming & 14 & 6 & 30 & 2 & 72.4 & $3^{\text {rd }}$ \\
Evaluation of Project & 11 & 6 & 20 & 8 & 71.1 & $4^{\text {th }}$ \\
Checklist & 12 & 7 & 14 & 8 & 61.9 & $5^{\text {th }}$ \\
Structured interview & 19 & 20 & 4 & 2 & 47.4 & $6^{\text {th }}$ \\
Questionnaire & 23 & 13 & 4 & 2 & 42.8 & $7^{\text {th }}$ \\
\hline
\end{tabular}

Source: Field survey, April 2013. 
In ranking the level of influence consultants have in assessing the risks identified, it came to light that contractual risk was ranked $1^{\text {st }}$. This indicates that consultants have a very significant influence when assessing contractual risks followed by financial $2^{\text {nd }}$ risk, economic risk $3^{\text {rd }}$, environmental risk $4^{\text {th }}$, technology risk $5^{\text {th }}$, social risk $6^{\text {th }}$, political risks $7^{\text {th }}$ and force majeure risks $8^{\text {th }}$. This is clearly tabulated in Table 7 providing a pictorial representation of the rankings of the various risks.

\section{Conclusions}

The paper aimed at exploring the approaches employed by consultants for risk assessment at the design phase of projects. To achieve the entire idea, two specific objectives were set for the study; to examine the extent of knowledge of consultants in risk assessment at the design phase; and to examine the influence of the consultant in risk assessment. Based on the literature reviewed in the study and the findings of the survey results, it can be concluded that all the research objectives have been achieved as follows; the study revealed that the extent of knowledge of consultants in risk assessment at the design phase is average. Finally the study revealed that consultants have a significant influence in risk assessment at the design phase.

To conclude, the interest in risk assessment is growing, with an increasingly and rapidly changing nature of projects, the onus falls on consultants to manage risk while maintaining control and improving performance. The recommendations proffered in this research would assist consultants in Ghana in assessing risk at the design phase of projects.

\section{Recommendation}

The findings of this research are expected to contribute to a more effective risk assessment process and therefore, benefit construction projects actors. To achieve this objective, the study proposes a set of recommendations to the consultants:

Table 7. Level of influence consultants have in assessing the following risks.

\begin{tabular}{ccccccc}
\hline Risk & Very Small & Fairly Small & Fairly Large & Very Large & RII & Rank \\
\hline Contractual Risk & - & 6 & 24 & 30 & 85.0 & $1^{\text {st }}$ \\
Financial Risk & 2 & 8 & 26 & 24 & 80.0 & $2^{\text {nd }}$ \\
Economic Risk & 4 & 15 & 27 & 14 & 71.3 & $3^{\text {rd }}$ \\
Environmental Risk & 4 & 18 & 22 & 16 & 70.8 & 4 th \\
Technological Risk & 9 & 16 & 21 & 10 & 64.3 & $5^{\text {th }}$ \\
Social Risk & 6 & 24 & 22 & 6 & 62.1 & $6^{\text {th }}$ \\
Political Risk & 19 & 14 & 15 & 10 & 55.9 & $7^{\text {th }}$ \\
Force Majeure Risk & 20 & 18 & 14 & 8 & 54.2 & $8^{\text {th }}$ \\
\hline
\end{tabular}

Source: Field survey, April 2013. 
- As many respondents identified the lack of theoretical knowledge, it would be reasonable to suggest advanced training in risk assessment for consultants. The training is expected to increase knowledge of the subject and understanding of the importance of risk assessment to safeguard project objectives. This recommendation is directed to the consultancy firms because they are responsible for staff development.

- Consultancy firms should develop a set of laid down procedures for consultants to use in risk assessment at the design phase of project in order that the use of intuition employed by majority of consultants in risk assessment is lessened.

\section{Recommendations for Further Research}

The findings of this research provide several directions for further work. For example, the study revealed a low participation of consultants in risk assessment at the design phase of projects in Ghana. In further research, participation of consultants in risk assessment should be explored. Another important finding is a knowledge gap in risk assessment at the design phase. Thus, a deeper study of the knowledge gap in risk assessment would be of particular interest.

\section{Acknowledgements}

My first and foremost thanks go to God Almighty, the foundation of life and the fountain of all knowledge; indeed he has been gracious to me throughout my life and I am very grateful to him.

My sincere gratitude and appreciation also go to Prof. E. Badu. My heartfelt thanks also go to Dr. D. Owusu Manu for his encouragement and direction in my work, your humble nature will forever influence my life. To my beloved parents, who have devoted their energies in making me who I am today, I am very grateful.

\section{Conflicts of Interest}

The author declares no conflicts of interest regarding the publication of this paper.

\section{References}

[1] Anvuur, A. and Kumaraswamy, M.S. (2006) Taking Forward Public Project Reforms in Ghana. CIB W107 Construction in Developing Countries International Symposium "Construction in Developing Economies. New Issues and Challenges", Santiago, 18-20 January 2006.

[2] Agyakwa-Baah, A. (2007) Stakeholders' Perceptions of the Causes of Delay on Construction Projects. BSc Dissertation, Kwame Nkrumah University of Science and Technology, Kumasi.

[3] Tuuli, M.M., Baiden, B.K. and Badu, E. (2007) Assessment and Enforcement of Liquidated Damages in Construction Contracts in Ghana. Structural Survey, 25, 204-219. https://doi.org/10.1108/02630800710772809 
[4] Agyakwa-Baah, A., Chileshe, N. and Stephenson, P. (2010) A Risk Assessment and Management Framework to Support Project Delivery. Proceedings. The 5 th Scientific Conference on Project Management, Advancing Project Management for the 21 st Century "Concepts, Tools and Techniques for Managing Successful Projects", Heraklion, 29-31 May 2010, 52-59.

[5] Latham, M. (1994) Constructing the Team. HMSO, London.

[6] Egan, S.J. (1998) Rethinking Construction. Department of the Environment, London.

[7] Ericsson, L.E. (2002) Skärpning Gubbar. SOU 2002:15, Byggkommissionen, Stockholm.

[8] Chan, A., Chan, D. and Ho, K. (2003) An Empirical Study of the Benefits of Construction Partnering in Hong Kong. Construction Management and Economics, 5 , 523-533. https://doi.org/10.1080/0144619032000056162

[9] Mahamid, I. (2013) Common Risks Affecting Time Overrun in Road Construction Projects in Palestine: Contractors' Perspective. Australian Journal of Construction Economics and Building, 12, 45-53. https://doi.org/10.5130/AJCEB.v13i2.3194

[10] Flanagan, R. and Norman, G. (1993) Risk Management and Construction. Blackwell Scientific, Oxford.

[11] Thompson, P.A. and Perry, J.G. (1992) Engineering Construction Risks: A Guide to Project Risk Analysis and Risk Management. Thomas Telford, London.

[12] Tadayon, M., Jaafar, M. and Nasri, E. (2012) An Assessment of Risk Identification in Large. Construction Projects in Iran. Journal of Construction in Developing Countries, 1, 57-69.

[13] Andi, S. and Minato, T. (2003) Design Documents Quality in the Japanese Construction Industry: Factors Influencing and Impacts on Construction Process. International Journal of Project Management, 21, 537-546. https://doi.org/10.1016/S0263-7863(02)00083-2

[14] Faridi, A. and El-Sayegh, S. (2006) Significant Factors Causing Delay in the UAE Construction Industry. Construction Management and Economics, 24, 1167-1176. https://doi.org/10.1080/01446190600827033

[15] Uher, E. and Toakley, R.A. (1999) Risk Management in the Conceptual Phase of a Project. International Journal of Project Management, 17, 161-169. https://doi.org/10.1016/S0263-7863(98)00024-6

[16] Aniekwu, A.N. and Okpala, D.C. (1988) The Effect of Systemic Factors in Contract Services in Nigeria. Construction Management and Economics, 6, 171-182. https://doi.org/10.1080/01446198800000015

[17] Kumaraswamy, M.M. (1994) Industry Development through Creative Project Packaging and Integrated Management. Engineering, Construction and Architectural Management, 5, 228-237. https://doi.org/10.1046/j.1365-232X.1998.00041.x

[18] Rwelamila, P.D., Talukhaba, A.A. and Ngowi, A.B. (1999) Tracing the African Project Failure Syndrome: The Significance of "Ubuntu”. Engineering, Construction and Architectural Management, 6, 335-346. https://doi.org/10.1046/j.1365-232x.1999.00120.x

[19] Hillebrandt, P.M. (2000) Economic Theory and the Construction Industry. 2nd Edition, Macmillan, Basingstoke. https://doi.org/10.1057/9780230372481

[20] Ofori, G. (2012) Developing the Construction Industry in Ghana: The Case for a Central Agency. MSc Project Dissertation, National University of Singapore, Singapore. 
[21] Lopes, J. (2012) Construction in the Economy and Its Role in Socio-Economic Development. Journal of Management in Engineering, 13, 41-49.

[22] World Bank (2003) Public Procurement Act of Ghana-Country Procurement Assessment Report. The World Bank, Washington DC, Report No. 29055.

[23] Chileshe, N. and Yirenkyi-Fianko, A.B. (2011) Perception of Threat Risk Frequency and Impact on Construction Projects in Ghana. Journal of Construction in Developing Countries, 16, 115-149.

[24] Smith, N.J., Tony, M. and Jobling, P. (2006) Managing Risk in Construction Projects. 2nd Edition, Blackwell Publishing, Oxford.

[25] Osipova, E. (2008) The Impact of Procurement Options on Risk Management in Swedish Construction Projects. Research Report, Lulea University of Technology, Luleå.

[26] Ayirebi-Dansoh, K. (2005) Strategic Planning Practice of Construction Firms in Ghana. Construction Management and Economics, 23, 163-168. https://doi.org/10.1080/0144619042000241435

[27] Eyiah, A.K. and Cook, P. (2003) Financing Small and Medium-Scale Contractors in Developing Countries: A Ghana Case Study. Construction Management and Economics, 21, 357-367. https://doi.org/10.1080/0144619032000111241

[28] World Bank (1996) Ghana 1996 Country Project Assessment Report. The World Bank, Washington DC.

[29] Bajaj, D., Oluwoye, J. and Lenard, D. (1997) An Analysis of Contractor's Approaches to Risk Identification in New South Wales, Australia. Construction Management and Economics, 15, 363-369. https://doi.org/10.1080/014461997372917

[30] Baker, S., Ponniah, D. and Smith, S. (1999) Risk Response Techniques Employed Currently for Major Projects. Construction Management and Economics, 4, 205-213. https://doi.org/10.1080/014461999371709

[31] Carter, E.E. (2002) What Are the Risk Analyses? Harvard Business Review, 5, 72-82.

[32] Wang, S., Dulaimi, M. and Aguira, M. (2004) Risk Management Framework for Construction Projects in Developing Countries. Construction Management and Economics, 22, 237-252. https://doi.org/10.1080/0144619032000124689

[33] Hull, J.C. (1990) The Evaluation of Risk in Business Investment. Pergamon Press, Oxford, 177-182.

[34] Hertz, D.B. and Thomas, H. (1995) Risk Analysis and Its Applications. John Wiley and Sons, Inc., New York.

[35] Tah, J.H.M. and Carr, V. (2001) Knowledge-Based Approach to Construction Project Risk Management. Journal of Computing in Civil Engineering, 13, 170-177. https://doi.org/10.1061/(ASCE)0887-3801(2001)15:3(170)

[36] Dehdasht, G., Zin, R. and Keyvanfar, A. (2015) Risk Classification and Barrier of Implementing Risk Management in Oil and Gas Construction Companies. Journal Technology of Sciences \& Engineering, 77, 161-169.

https://doi.org/10.11113/jt.v77.6413

[37] Paulson, U. (2007) On Managing Disruption Risks in the Supply Chain-The DRISC Model. KFS I Lund Ab. Lund.

[38] Deviprasadh, A. (2007) Risk Assessment and Management in Construction Projects. MSc Dissertation, Anna University, Chennai.

[39] Baloi, D. and Price, A.D.F. (2003) Modelling Global Risk Factors Affecting Construction Cost Performance. International Journal of Project Management, 11, 
33-40.

[40] Barber, R.B. (2005) Understanding Internally Generated Risks in Projects. International Journal of Project Management, 10, 252-260.

[41] Chapman, C. and Ward, S. (2002) Managing Project Risk and Uncertainty: A Constructively Simple Approach to Decision Making. Wiley, Chichester.

[42] IEC (2001) Project Risk Management-Application Guidelines, International Standard. IEC, Genève.

[43] Jaafari, A. (2001) Management of Risks, Uncertainties and Opportunities on Projects: Time for a Fundamental Shift. International Journal of Project Management, 19, 89-101. https://doi.org/10.1016/S0263-7863(99)00047-2

[44] Project Management Institute S.C. (2008) A Guide to the Project Management Body of Knowledge. 7th Edition, PMI Communications Publishing, Pennsylvania.

[45] Songer, A.D., Diekmann, J. and Pecsok, R.S. (1997) Risk Analysis for Revenue Dependent Infrastructure Projects. Construction Management and Economics, 15, 377-382. https://doi.org/10.1080/014461997372935

[46] Mubarak, S. (2010) Construction Project Scheduling and Control. 2nd Edition, John Wiley and Sons Inc., Hoboken. https://doi.org/10.1002/9780470912171

[47] Standards Australia/Standards New Zealand (1999) Risk Management. Australian/New Zealand Standard. AS/NZS4360.

[48] BSI (2000) British Standards Institution.

[49] Canadian Standards Association (1997) Risk Management: Guideline for Decision-Makers (CAN/CSA-Q850-97). Canadian Standards Association, Rexdale.

[50] Akintoye, A.S. and MacLeod, M.J. (1997) Risk Analysis and Management in Construction. International Journal of Project Management, 15, 31-38. https://doi.org/10.1016/S0263-7863(96)00035-X

[51] Lyons, T. and Skitmore, M. (2004) Project Risk Management in the Queensland Engineering Construction Industry: A Survey. International Journal of Project Management, 22, 51-61. https://doi.org/10.1016/S0263-7863(03)00005-X

[52] Burns, N. and Grove, S.K. (2001) The Practice of Nursing Research: Conduct, Critique and Utilization. 4th Edition, WB Saunders, Philadelphia.

[53] Kish, L. (1965) Survey Sampling. John Wiley and Sons Inc., New York.

[54] Ploit, D. and Beck, C. (2006) The Content Validity Index: Are You Sure You Know What's Being Reported? Critique and Recommendations. Research in Nursing and Health, 29, 489-497. https://doi.org/10.1002/nur.20147

[55] Mouton, J. (2001) How to Succeed in Your Master's and Doctoral Studies: A South African Guide and Resource Book. Van Schaik Publishers, Hatfield.

[56] Robson, C. (2002) Real World Research: Recourse for Social Scientists and Practitioner-Researcher. Oxford Blackwell Publishing, Oxford.

[57] Naoum, S.G. (2007) Dissertation Research and Writing for Construction Students. 2nd Edition, Butterworth-Heinemann, Cambridge.

[58] Tang, W., Qiang, M., Duffield, C., Young, D.M. and Lu, Y. (2007) Risk Management in the Chinese Construction Industry. Journal of Construction Engineering and Management, 133, 944-955. https://doi.org/10.1061/(ASCE)0733-9364(2007)133:12(944) 